ISSN: $1412-8837$

\title{
ANALISIS POLA DAN RESIKO USAHA GULA AREN DI KABUPATEN REJANG LEBONG
}

\author{
(ENTERPRISE MODEL AND RISK ANALYSIS OF PALM SUGAR \\ INDUSTRIES IN REJANG LEBONG REGENCY)
}

\author{
Felycia Tiera Kencana, Ketut Sukiyono, Bambang Sumantri \\ Jurusan Sosial Ekonomi Pertanian, Fakultas Pertanian Universitas Bengkulu \\ ksukiyono@yahoo.com
}

\begin{abstract}
This study is aimed at examining enterprises model and analysing risk level of Palm Sugar in Rejang Lebong Regency. Risk Analysis involve nira harvested, nira processed, palm sugar production, and palm sugar prices received by producers. Twostages cluster sampling method is used to determine research areas, i.e, subdistrict of Sindang Kelingi and Selupu Rejang based on the numbers of firms. Using similar critirea, two villages are selected, i.e, Air Meles Atas and Sindang Jati. From those villages, then, 86 palm sugar producers are selected using Simple Random Sampling. Descriptive analysis is applied to describe entreprises model of palm sugar industries while risks is analysed using its varians, standard deviation, and minimum level of production as proposed by Maryam and Suprapti (2008). The research shows that all palm sugar industries in this regency can be categories as home industries with average production scale of $11.58 \mathrm{~kg}$ per process in rainy season and $11.54 \mathrm{~kg}$ in dry season. Palm sugar producers use their own capital to produce palm sugar and borrowed to palm sugar village merchants when they need. From risk analysis, the study finds that palm sugar producers will face higher risk in term of nira harvested and processed, and production in dry season, except in term of price received which is higher in rainy season. Over all, palm sugar producers will not face risk significantly both in dry and rainy season.
\end{abstract}

Key words: Palm Sugar, Enterprises model, Risk analysis

\section{PENDAHULUAN}

Sebagai komoditi unggulan di Kabupaten Rejang Lebong, gula aren banyak diusahakan oleh masyarakat di daerah ini. Data yang dipublikasikan oleh Dinas Perindustrian dan Perdagangan Rejang Lebong (2010) menyebutkan bahwa terdapat 2687 unit usaha gula aren yang ada di Kabupaten Rejang 
Lebong yang tersebar di 10 kecamatan. Prospek komoditi ini semakin menjanjikan karena bahan baku untuk pembuatan gula aren ketersediaannya berlimpah dalam menunjang pengembangan industri kecil gula aren. Namun peluang pasar yang menjanjikan keuntungan besar serta didukung oleh bahan baku yang besar, belum mampu dimanfaatkan oleh industri pengolahan gula aren secara maksimal. Ada beberapa kendala yang mungkin dihadapi oleh pengrajin gula aren dalam mengembangkan usahanya. Pengrajin gula aren tampaknya masih memiliki keterbatasan dalam permodalan, pemasaran dan teknologi yang digunakan. Lebih lanjut, seperti usaha pada bidang lain, pengrajin gula aren juga akan dihadapkan pada resiko. Resiko yang dihadapi tidak saja resiko harga tetapi juga resiko untuk memperoleh nira yang disadap serta resiko produksi.

Berangkat dari diskusi di atas, penelitian untuk menjelaskan bagaimana bentuk pola usaha gula aren dan besarnya resiko usaha gula aren di Kabupaten Rejang Lebong. Penelitian ini bertujuan untuk menelaah pola usaha gula aren di Kabupaten Rejang Lebong dan untuk mengetahui besarnya resiko usaha gula aren di Kabupaten Rejang Lebong. Hasil penelitian ini diharapkan dapat memecahkan permasalahan yang dihadapi oleh petani khususnya terkait dengan reskio usaha gula aren.

\section{METODE PENELITIAN}

Lokasi penelitian ditentukan dengan metode two-stages cluster sampling. Tahap Pertama, memilih Kecamatan Sindang Kelingi dan Kecamatan Selupu Rejang dengan dasar banyaknya industri kecil gula aren. Selanjutnya dari masing - masing kecamatan dipilih dua desa dengan kriteria pemilihan yang sama, yaitu desa Air Meles Atas dan Sindang Jati. Data diperoleh dari 5 kali proses produksi secara berurutan masing-masing pada musim hujan dan kemarau. Metode penentuan responden dilakukan secara dilakukan dengan menggunakan metode sampling acak sederhana (Simple Random Sampling) yaitu sebanyak 86 pengrajin gula aren. Penentuan jumlah sampel ini dilakukan dengan menggunakan rumus yang dikemukan oleh Sheaffer et al (1990).

Telaah tentang pola usaha gula aren digunakan dengan menggunakan analisis deskriptif baik secara kuantitatif maupun kualitatif. Meleong (2004) dan Sukandarrumidi (2004), dalam analisa deskriptif kuantitatif akan disajikan melalui proses kodetifikasi, kategorisasi, interpretasi, pemaknaan dan abstraksi. Dengan analisa ini akan diperoleh gambaran tentang variasi-variasi yang berkaitan dengan subjek dan objek penelitian. Sementara itu, besarnya resiko gula aren di Kabupaten Rejang Lebong dianalisa dengan menggunakan rumus seperti yang digunakan oleh Maryam dan Suprapti (2008) sebagai berikut:

Hasil yang diharapkan (E) menghitung jumlah nira, produksi, dan harga ratarata hasil yang diharapkan yang diestimasi dengan nilai rata - ratanya sebagai berikut: 


$$
E=\frac{\sum_{i=1}^{n} \sum_{j=1}^{t} E i j}{n t}
$$

dimana $\mathrm{E}$ adalah rata - rata nira, produksi, dan harga yang diharapkan, Eij adalah jumlah nira, produksi dan harga yang diterima oleh pengrajin ke i dan proses produksi ke j. Jumlah responden adalah 86 pengrajin gula aren dan ada 5 proses produksi.

Besarnya resiko yang dihadapi oleh pengrajin gula aren diestimasi secara statistik dengan melihat besaran ragam dan simpangan bakunya. Besarnya ragam (variances) dihitung dengan formula sebagai berikut:

$$
V^{2}=\frac{\sum_{i=1}^{n} \sum_{j=1}^{t}(E i j-E)^{2}}{n-1}
$$

dimana $\mathrm{V}^{2}$ adalah Ragam, Eij adalah besarnya nira, produksi, harga yang diterimea pengrajin ke i pada proses produksi ke $j$, E adalah jumlah nira, produksi, harga yang diharapkan. Sementara itu, simpangan baku diperoleh dari akar nilan variannya, yakni sebagai berikut:

$$
V=\sqrt{V^{2}}=\sqrt{\frac{\sum_{i=1}^{n} \sum_{j=1}^{t}(E i j-E)^{2}}{n-1}}
$$

Menurut Hernanto (1993) dalam Maryam dan Suprapti (2008), Koefisien Variasi (KV) merupakan perbandingan antara besarnya resiko yang dihadapi dengan hasil yang diharapkan. Koefisien variasi merupakan perbandingan antara resiko yang harus ditanggung pengrajin dengan batas bawah yang diperoleh sebagai hasil dari sejumlah modal yang diinvestasikan dalam proses produksi. KV dapat dirumuskan sebagai berikut:

$$
K V=\frac{V}{E}
$$

dimana KV adalah Koefisien Variasi, V adalah simpangan baku, dan E adalah hasil rata-rata.

Batas bawah hasil tertinggi merupakan nilai hasil produksi yang paling rendah yang mungkin diterima. Apabila nilainya kurang dari nol, maka kemungkinan besar akan mengalami kerugian, begitu sebaliknya. Batas bawah dapat dihitung denganrumus sebagai berikut:

$$
\mathrm{L}=\mathrm{E}-2 \mathrm{~V}
$$

dimana L adalah Batas bawah, E adalah Rata-rata produksi yang diperoleh $(\mathrm{Kg}), \mathrm{V}$ adalah simpangan baku. Kriteria pengujian hubungan antara batas bawah dengan koefisien variasi adalah sebagai berikut: (a) Jika KV $>1 / 2 \mathrm{~L}<0$ artinya ada peluang kerugian yang di derita oleh pengrajin gula aren atau resiko 
yang diderita besar, dan (b) Jika KV $<1 / 2 \mathrm{~L} \geq 0$ artinya pengrajin gula aren selalu terhindar dari kerugian atau resiko yang diderita kecil.

\section{HASIL DAN PEMBAHASAN}

\section{Karakteristik Pengrajin Gula Aren}

Hasil penelitian menunjukkan bahwa rata-rata umur pengrajin gula aren adalah sekitar 44 tahun sebanyak 72,09 \%. Ini menunjukkan bahwa rata-rata umur pengrajin masih berada pada usia yang produktif. Menurut pendapat Mubyarto (1989) usia produktif berkisar antara 15 - 65 tahun. Dimana pada usia ini pengrajin gula aren akan berusaha menghasilkan produkstivitas kerja yang maksimal. Dilihat dari tingkat pendidikan, tingkat pendidikan formal sebagian besar pengrajin gula aren adalah 7 tahun sebanyak 66,28 persen. Artinya, pengolah gula aren telah dapat melalui pendidikan formal tamat SD meskipun tidak bisa menyelesaikan atau tidak tamat SLTP. Rendahnya tingkat pendidikan ini diduga oleh faktor ekonomi dan ketersediaannya sarana pendidikan pada saat itu.

Hasil penelitian menunjukkan bahwa pengalaman berusaha pengrajin gula aren pada skala usaha besar lebih banyak berada pada kisaran 6 - 41 tahun sebanyak 70,93 persen, dengan pengalaman berusaha gula aren rata-rata selama 18,81 tahun. Luas lahan yang dimiliki oleh pengrajin gula aren yang dimanfaatkan untuk penanaman pohon aren dan memiliki luas lahan seluas 1 ha berada pada kisaran 0,25 - 3 ha.

\section{Analisis Pola Usaha Gula Aren}

Fokus analisa pada pola usaha adalah cara pengrajin gula aren mendapatkan input produksinya, khususnya nira, teknologi yang digunakan dalam proses produksi dan sasaran pemasaran hasil outputnya. Nira yang akan diolah atau diproses menjadi gula aren berasal dari hasil deres pada pohon aren yang dikuasai oleh pengrajin gula aren. Hasil penelitian menunjukkan bahwa jumlah pohon aren yang dikuasai oleh pengrajin gula aren rata - rata sebanyak 12,38 batang yang tersebar pada lahan yang dikuasai yakni rata - rata seluas 1,08 ha. Ini berarti bahwa tidak semua lahan yang dikuasai oleh pengrajin ditanami dengan pohon aren. Dengan kata lain, tanaman aren bukan merupakan tanaman utama pada lahan yang dikuasai oleh pengrajin. Jika dilihat dari pekerjaan sampingan dimana 89,53 \% adalah petani kopi, maka bisa dipastikan bahwa tanaman utama pada lahan petani adalah kopi.

Rata - rata tingkat produktivitas pohon aren yang dikuasai pengajin gula aren adalah 5.38 liter per pohon pada musim hujan dan 5.15 liter per pohon pada musim kemarau. Produktivitas pohon aren ini relatif kecil jika dibandingkan dengan potensi produktivitas pohon aren, dimana menurut Burhanudin, dkk (2005) setiap pohon aren dapat menghasilkan 10 liter nira 
setiap hari dengan penyadapan dua kali yakni pagi dan sore. Rendahnya produktivitas ini mungkin disebabkan oleh umur tanaman aren, tidak adanya pemeliharaan tanaman, dan sudah lewatnya masa penyadapan. Data yang disajikan menunjukkan bahwa 98,84 \% pengrajin gula aren miliki lahan sendiri. Data ini juga berimplikasi bahwa tanaman aren yang ada di lahan adalah milik pengrajin gula aren. Dengan demikian, ketersediaan bahan baku gula aren, yakni nira, juga tidak menjadi permasalahan utama bagi pengrajin. Dari pohon yang ada, jumlah nira yang dihasilkan (dideres) rata - rata sebanyak 68,32 liter dan 65,29 liter untuk musim hujan dan musim kemarau per proses produksi. Tenaga kerja yang digunakan menggunakan tenaga kerja dari dalam keluarga.

Teknologi yang digunakan dalam proses pengolahan gula aren ini masih sederhana. Artinya, pengrajin gula aren menggunakan peralatan yang sederhana seperti tangga, bronang, tempurung kelapa, sutil, pengaduk kayu, saringan, sabut kelapa, parang, tungku masak, sendok pengaduk, rak dari bambu untuk tempurung dan kuali. Hasil penelitian menunjukkan bahwa $85 \%$ pengrajin gula aren mengatakan bahwa teknologi yang digunakan mudah sekali digunakan dan tidak memerlukan keterampilan khusus. Di samping itu, mereka (67 \%) juga mengatakan bahwa teknologi itulah yang saat ini tersedia di lokasi usaha mereka. Temuan ini sama dengan temuan penelitian yang dilakukan oleh Leatemea di desa Tuhaha kecamatan Saparua, Kabupaten Maluku Tengah. Pengrajin di desa ini juga masih menggunakan teknologi yang masih sederhana dan belum modern.

Produksi gula aren yang dihasilkan setiap proses produksi adalah 11,58 $\mathrm{kg}$ / proses pada musim hujan dan $11,54 \mathrm{~kg} /$ proses pada musim kemarau. Adanya perbedaan ini utamanya disebabkan oleh perbedaan jumlah nira yang diolah dimana pada musim hujan jumlah nira yang diolah lebih banyak daripada musim kemarau.

Jumlah nira rata - rata yang diproses dibagi dengan jumlah produksi akan diperoleh perkiraan rendemen nira yang dihasilkan baik pada musim hujan maupun musim kemarau. Rendemen nira di daerah penelitian adalah 17,04\% dan 17,66 \% masing - masing pada musim hujan dan kemarau. Dengan kata lain, satu kilogran gula aren dibutuhkan 5,87 liter nira pada musim hujan dan 5,66 liter pada musim kemarau. Rendemen ini lebih tinggi daripada rendemen nira yang dikeluarkan oleh Pusdatin Deptan (2012), yakni 14,6 - 16 \%. Yang perlu dicatat, angka rendemen ini adalah rendemen rata - rata nasional yang tentunya untuk setiapk daerah akan berbeda - beda tingkat rendemennya. Perbedaan rendemen ini diduga banyak disebabkan oleh kondisi tanaman, iklim, lokasi tanaman.

Sasaran dan pemasaran hasil output dari pengolahan gula aren ke pedagang pengumpul tingkat desa. Sebagian pengrajin ada yang langsung menjual ke pasar induk di Curup serta tidak banyak yang menjual langsung ke konsumen akhir. Rantai pemasaran ini tampaknya sama seperti yang terjadi di desa Kuta Raja Tanah Karo Sumatera Utara yang hanya melibatkan pengrajin, pembeli tingkat desa dan pengecer yang ada (Wibowo dan Sasmiko 2005). Keduanya saling melengkapi dan membutuhkan sehingga kontinuitas usaha 
tetap terjaga. Meskipun kemitraan antara pengrajin gula aren dan pedagang pengumpul yang terjalin tidak di buat dalam bentuk tertulis sehingga tidak memiliki kekuatan hukum. Terkait dengan harga yang diterima oleh pengrajin, rata - rata harga yang diterima oleh pengrajin gula aren tidak banyak perbedaan. Harga yang diterima oleh pengrajin rata - rata sebesar Rp. $11.937,907$ per $\mathrm{kg}$ pada musim hujan dan Rp. 11.923,256 per kg pada musim kemarau.

\section{Analisa Resiko Usaha Gula Aren}

Pendekatan analisa resiko didasarkan kepada periode produksi yang diperoleh oleh pengrajin gula aren dalam 2 musim, yaitu musim hujan dan musim kemarau. Data yang digunakan untuk menganalisis resiko pengrajin gula aren adalah data produksi gula aren, jumlah nira yang disadap, jumlah nira yang diolah, produksi dan harga gula aren yang diterima produsen gula aren.

\section{Resiko Nira yang Disadap}

Nilai varians $\left(\mathrm{V}^{2}\right)$ adalah jumlah nira yang disadap dimusim kemarau lebih tinggi daripada jumlah nira di musim hujan $(2,86>2,22)$. Nilai simpangan baku (V) jumlah nira musim kemarau lebih tinggi daripada dimusim hujan yaitu $(1,69>1,49)$, sehingga resiko jumlah nira yang dihasilkan pada musim kemarau lebih tinggi daripada musim hujan. Tingginya varian dan simpangan baku menunjukkan tingginya fluktuasi jumlah nira yang dapat dideres. Oleh sebab itu, nilai varian yang tinggi berarti tinggi pula resikonya. Temuan tentang musim kemarau lebih beresiko dibandingkan dengan musim hujan adalah wajar karena banyak tidaknya nira juga tergantung pada banyak sedikitnya jumlah air yang dapat diserap oleh tanaman.

Nilai koefisien variasi (KV) dimusim kemarau lebih tinggi dibandingkan dimusim hujan $(0,03>0,02)$. Hal ini berarti pengambilan nira pada musim kemarau akan mengalami resiko. Sementara itu, nilai batas bawah (L) yang dapat diartikan sebagai nilai jumlah nira yang paling rendah yang mungkin diterima oleh pengrajin yang melakukan pengolahan gula aren dimusim hujan adalah sebesar 65,34 liter, sedangkan batas bawah produksi tertinggi (L) dimusim kemarau sebesar 61,91 liter. Penyadapan nira dilakukan dua kali sehari yaitu pagi dan sore hari. Setiap kali pemungutan nira yang tertampung dilakukan lagi pengirisan pada tandan bunga yang telah diambil niranya. Nira aren didapat dengan cara menyadap tandan bunganya tetapi yang disadap hanya bunga jantan yang telah dewasa (Sunanto, 1993)

Jika dianalisa lebih jauh, setengah dari nilai $\mathrm{L}$ ini lebih besar dari nol dan juga lebih besar dari koefisien variasi (KV), maka dapat diduga bahwa pengrajin gula aren akan selalu terhindar dari kerugian atau resiko yang diderita akan kecil sekali, baik pada musim hujan maupun musim kemarau. 
Tabel 1. Analisis Resiko Usaha Gula Aren

\begin{tabular}{|c|c|c|c|c|c|c|c|c|}
\hline \multirow{2}{*}{$\begin{array}{c}\text { Proses } \\
\text { produksi } \\
\text { ke- }\end{array}$} & \multicolumn{2}{|c|}{$\begin{array}{c}\text { Nira yang } \\
\text { disadap }\end{array}$} & \multicolumn{2}{|c|}{$\begin{array}{r}\text { Nira yang } \\
\text { diproses } \\
\end{array}$} & \multicolumn{2}{|c|}{ Produksi } & \multicolumn{2}{|c|}{ Harga } \\
\hline & Hujan & Kemarau & Hujan & Kemarau & Hujan & Kemarau & 1 Hujan & Kemarau \\
\hline 1 & 67,07 & 66,56 & 67,07 & 66,56 & 11,90 & 11,90 & 11.877 & 11.943 \\
\hline 2 & 67,07 & 66,52 & 66,38 & 66,67 & 11,80 & 11,78 & 11.893 & 11.905 \\
\hline 3 & 67,86 & 66,28 & 67,38 & 66,45 & 11,31 & 11,32 & 11.883 & 11.853 \\
\hline 4 & 69,01 & 64,31 & 68,84 & 64,34 & 11,58 & 11,51 & 11.980 & 11.939 \\
\hline 5 & 70,57 & 62,77 & 70,31 & 62,77 & 11,31 & 11,20 & 12.054 & 11.974 \\
\hline Rerata (E) & 68,32 & 65,29 & 68,00 & 65,36 & 11,58 & 11,54 & $11.937,907$ & $11.923,256$ \\
\hline Varians (V & 2,22 & 2,86 & 2,48 & 3,03 & 0,07 & 0,09 & $5.992,834$ & $2.111,276$ \\
\hline $\begin{array}{l}\text { Simp. Baku } \\
\text { (V) }\end{array}$ & 1,49 & 1, & 1,57 & 1,74 & 0,27 & 0 & 7 & 45 \\
\hline $\mathrm{KV}$ & 0,02 & 0,03 & 0,02 & 0,03 & 0,02 & 0,03 & 0,006 & 0,004 \\
\hline $\mathrm{L}$ & 65,34 & 61,91 & 64,85 & 61,88 & 11,04 & 10,95 & $11.783,080$ & $11.831,359$ \\
\hline
\end{tabular}

Sumber : Data Primer diolah (2012)

Hasil uji $\mathrm{t}$ yang dilakukan didapatkan bahwa nilai $\mathrm{t}_{\text {hitung }}$ lebih kecil dari $t_{\text {tabel }}$ pada taraf kepercayaan $5 \%$, yakni 0,69 $<1,990$. Hasil uji menyimpulkan bahwa tidak ada perbedaan yang nyata terhadap jumlah nira yang dideres pada musim hujan ataupun pada musim kemarau.

Temuan ini wajar karena proses produksi nira oleh pohon aren tidak dipengaruhi oleh musim tetapi lebih dipengaruhi oleh umur tanaman dan masa produksi nira itu sendiri. Temuan ini sama seperti laporan yang disampaikan Kompas (Senin, 24 Oktober 2011) di Kabupaten Lampung Barat yang melaporkan bahwa produksi gula aren dipengaruhi dengan hasil sadapan air nira dan selama kemarau perolehan air nira tidak mengalami penurunan.

\section{Resiko Nira yang Diproses}

Nira yang dibawa menuju tempat pengolahan dapat juga hilang diperjalanan baik karena tumpah atau penguapan. Oleh sebab itu, pengrajin akan dihadapkan kehilangan jumlah nira yang akan diproses menjadi gula aren. Hasil penelitian menujukkan bahwa rata-rata (E) jumlah nira yang diproses di musim hujan sebesar 68,00 liter dan 65,36 liter di musim kemarau. Jumlah nira yang dapat diolah lebih lanjut menjadi gula aren pada musim kemarau ternyata lebih beresiko dibandingkan pada hujan. Kesimpulan ini didasarkan pada nilai $\mathrm{V}^{2}$ dan $\mathrm{V}$ dimana nilai varians $\left(\mathrm{V}^{2}\right)$ adalah jumlah nira yang diproses dimusim kemarau lebih tinggi daripada jumlah nira dimusim hujan, yakni 3,03 > 2,48. Nilai simpangan baku (V) jumlah nira yang diproses musim kemarau juga lebih tinggi daripada dimusim hujan yaitu 1,74 $>1,57$.

Nilai koefisien variasi $(\mathrm{KV})$ nira yang diproses dimusim kemarau lebih tinggi dibandingkan dimusim hujan yaitu sebesar $0,03>0,02$. Hal ini berarti 
jumlah nira yang diolah pada musim kemarau akan mengalami resiko di masa akan datang lebih besar dibandingkan dengan melakukan pengolahan gula aren dimusim hujan. Nilai batas bawah (L) adalah nilai jumlah nira yang diproses yang paling rendah yang mungkin diterima oleh pengrajin yang melakukan pengolahan gula aren dimusim hujan adalah sebesar 64,85 liter, sedangkan batas bawah produksi tertinggi (L) dimusim kemarau sebesar 61,88 liter.

Kalau dilihat nilai $1 / 2 \mathrm{~L}$, baik pada musim kemarau dan hujan, nilai $1 / 2 \mathrm{~L}$ jumlah nira yang lebih besar dari nol dan KV-nya menunjukkan bahwa pengrajin gula aren akan selalu terhindar dari kerugian atau resiko yang diderita akan kecil sekali. Hal ini juga ditunjukkan oleh tidak adanya perbedaan yang nyata antara jumlah nira uyang diproses pada musim hujan dan musim kemarau. Tidak adanya perbedaan ini ditujukkan oleh uji t dimana dimana nilai $t_{\text {hitung }}$ lebih kecil dari $t_{\text {tabel }}$ pada taraf kepercayaan $5 \%$, yakni 0,56 $<1,990$. Temuan ini wajar karena jumlah nira yang disadap pada musim kemarau juga tidak berbeda nyata dengan jumlah nira yang disadap pada musim hujan seperti yang dijelaskan di atas.

\section{Resiko Produksi gula aren}

Nilai varians $\left(\mathrm{V}^{2}\right)$ adalah produksi gula aren di musim kemarau lebih tinggi daripada produksi gula aren dimusim hujan $(0,09>0,07)$ dengan demikian resiko produksi musim kemarau lebih tinggi daripada produksi gula aren dimusim hujan. Nilai simpangan baku (V) produksi gula aren musim kemarau lebih tinggi daripada dimusim hujan yaitu $(0,30>0,27)$, sehingga resiko produksi gula aren di musim kemarau lebih tinggi daripada produksi gula aren dimusim hujan.

Nilai koefisien variasi (KV) dimusim kemarau lebih tinggi dibandingkan dimusim hujan $(0,03>0,02)$. Hal ini berarti dalam melakukan pengolahan gula aren dimusim kemarau pengrajin akan mengalami resiko produksi di masa akan datang lebih besar dibandingkan dengan melakukan pengolahan gula aren dimusim hujan. Lebih lanjut, nilai batas bawah (L) yang dapat diartikan sebagai nilai produksi yang paling rendah yang mungkin diterima oleh pengrajin yang melakukan pengolahan gula aren di musim hujan adalah sebesar 11,04 $\mathrm{kg} /$ proses produksi, sedangkan batas bawah produksi gula aren (L) di musim kemarau sebesar 10,95 kg/proses produksi.

Dengan menggunakan nilai batas bawah ini, maka dapat disimpulkan bahwa pengrajin gula aren akan selalu terhindar dari kerugian atau resiko produksi yang diderita akan kecil sekali. Kesimpulan ini didasarkan pada temuan yang menunjukkan bahwa nilai $K V<1 / 2 \mathrm{~L}$, dan nilai $1 / 2 \mathrm{~L} \geq 0$. Hasil ini juga didukung oleh hasil uji $\mathrm{t}$ yang menyimpulkan tidak ada perbedaan resiko produksi yang dihasilkan pada musim hujan dan musim kemarau. 


\section{Resiko Harga}

Hasil analisis data menunjukan bahwa harga jual gula aren dimusim hujan lebih tinggi dari pada harga jual gula aren di musim kemarau. Harga jual ratarata di musim kemarau Rp. 11.923,25/kg sementara harga jual rata -rata musim hujan Rp. 11.937,907/kg. Harga jual gula aren dimusim hujan lebih tinggi di bandingkan dengan gula aren dimusim kemarau, karena dimusim hujan kualitas gula aren lebih baik dibandingkan musim kemarau. Harga jual yang berlaku ditingkat pengrajin setiap kali proses produksi bervariasi antara pengrajin satu dengan pengrajin lainnya. Harga jual di tingkat pengrajin terendah Rp.11.000/Kg dan harga tertinggi Rp.13.000/Kg.

Jika dibandingkan dengan musim hujan, resiko harga yang diterima oleh pengrajin pada musim hujan lebih tinggi. Hal ini tercermin dari nilai varians $\left(\mathrm{V}^{2}\right)$ adalah harga jual gula aren di musim hujan lebih tinggi daripada harga jual dimusim kemarau, yaitu $R p 5.992,834>\operatorname{Rp} 2.111 .276$, dan juga nilai nilai simpangan baku (V) harga jual, yaitu $(77,413>45,949)$. Salah satu penyebabnya adalah kualitas gula aren yang baik dan sulitnya pengrajin dalam pengambilan bumbung dari pohon satu ke pohon lainnya.

Nilai koefisien variasi (KV) harga gula aren dimusim hujan lebih tinggi dibandingkan musim kemarau yaitu sebesar $0,006>0,004$. Hal ini berarti harga yang diterima oleh pengrajin gula aren pada musim hujan akan mengalami resiko di masa akan datang lebih besar dibandingkan dengan melakukan pengolahan gula aren di musim kemarau.

Untuk nilai batas bawah (L) adalah harga yang paling rendah diterima oleh pengrajin yang melakukan pengolahan gula aren dimusim kemarau adalah Rp.11.831,359, sedangkan batas bawah produksi tertinggi (L) dimusim penghujan sebesar Rp.11.783,080. Dengan menggunakan nilai batas bawah ini, maka nilai $\mathrm{KV}<1 / 2 \mathrm{~L}$, dan nilai $1 / 2 \mathrm{~L} \geq 0$. Ini berarti, pengrajin gula aren akan selalu terhindar dari kerugian atau resiko harga yang diterima akan kecil sekali. Tidak signifikannya perbedaan harga yang diterima pengrajin pada musim hujan dan musim kemarau menyebabkan pengrajin tidak mengalam resiko yang besar pada harga.

\section{SIMPULAN DAN SARAN}

\section{Simpulan}

Pola usaha gula aren yang dilakukan masih bersifat industri rumah tangga yang ditandai dengan masih, serta rendahnya skala produksi yang dihasilkan kecilnya jumlah pohon aren yang dikuasai. Umumnya pengrajin mendapatkan modal usaha dari dalam keluarga, serta menjual produk ke pengumpul tingkat desa (taoke) dengan harga yang menjadi kesepakatan mereka. 
Resiko yang lebih besar pada musim kemarau dibandingkan dengan dibandingkan dengan pengolahan gula aren pada musim hujan, khususnya terhadap resiko nira yang diperoleh, nira yang diproses dan produksi gula aren. Resiko harga yang tinggi akan dialami pengrajin pada musim hujan dibandingkan dengan musim kemarau. Namun secara keseluruhan, pengrajin gula aren tidak mengalami resiko terhadap nira yang diperoleh, nira yang diproses, produksi, dan harga yang diterima baik pada musim hujan dan musim kemarau.

\section{Saran}

Pola usaha pengolahan gula aren sudah cukup baik, namun perlu dilakukan upaya - upaya peningkatan produktivitas pohon aren melalui peremajaan tanaman, pemeliharaan pohon aren. Disamping itu, pengrajin perlu juga dikenalkan upaya - upaya peningkatan nilai tambah gula aren menjadi gula semut.

Terkait dengan resiko, pengrajin gula aren hendaknya dapat diberikan informasi harga baik oleh pemerintah maupun instansi yang terkait. Tidak kalah pentingnya adalah perlu adanya penguatan posisi tawar pengrajin gula aren melalu penguatan kelembagaan pengrajin gula

\section{DAFTAR PUSTAKA}

Baharuddin, Musrizal Muin, Dan Herniaty Bandaso. 2007. Pemanfaatan Nira Aren (Arenga Pinnata Merr) Sebagai Bahan Pembuatan Gula Putih Kristal. Jurnal Perennial, 3(2) : 40-43

Dinas Perindustrian dan Perdagangan Rejang Lebong. 2010. Profil UKM Kabupaten Rejang Lebong. Curup.

Kompas, 2011. Musim Kemarau, Produksi Gula Aren Stabil. Senin, 24 Oktober 2011 diunduh pada 06:46 WIB

Leatemia, D. Ester. 2008. Analisis Finansial Usaha Agroindustri Gula Aren. Jurnal Ichsan Gorontalo. 3(1) : 1351-1359.

Maryam Syarifah, Suprapti, 2008. Studi Banding Resiko Ekonomi Usaha Tani Pepaya Varietas Thailand dan Hawaii. EPP. 5(1) : 8-15

Moleong, L.J. 2004. Metodologi Penelitian Kualitatif. Ed. 1, Cet. Ke-18. PT Remaja Rosdakarya, Bandung.

Mubyarto, 1986. Pengantar Ekonomi Pertanian. LP3ES. Jakarta.

Pusdatin Deptan 2012. Diunduh dari http://pusdatin.deptan.go.id/ statistik/metodologi_Bun/BAB IV. Cakupan Data dan Besaran Parameter yang Dibakukan.pdf pada tanggal 9 Maret 2012. 